\title{
The General Model of Golden Horde Architectural Decor
}

\author{
Dr. Khaled Al Omari ${ }^{1}$, Prof. Safwan Al Salaimeh², Dr. Musa Sagin ${ }^{3}$, \\ ${ }^{1}$ Architecture department, Faculty of Engineering, University of Jordan, Visiting professor Aqaba University of Technology, \\ Aqaba, Jordan. \\ ${ }^{2}$ Department of Software Engineering, information technology Faculty, Aqaba University of Technology, Aqaba, Jordan.
}

${ }^{3}$ Department of architecture, Faculty of Engineering, Aqaba University of Technology, Aqaba, Jordan.

ORCID: 0000-0002-8474-3471 (Safwan Ali)

\begin{abstract}
The constant processes of interaction between cultures of different countries and religions that took place in it contributed to the prosperity of trade, science, and art. In addition, handicraft production was highly developed in Uchi Jochi. Urban craft included jewelry, pottery, construction, weaving, carving on various materials, various types of metalworking, etc. This diversity was due to the constant need for supply of many Golden Horde cities.

The article provides an overview of the main types of the Golden Horde architectural decor. The study used generalized data from archaeological studies of the cities of the Golden Horde.
\end{abstract}

Keywords: handicraft, prosperity, archaeological, establishment, décor, construction.

\section{Introduction:}

The Golden Horde (Ulus Juchi), which arose in the second half of the 13th century, became one of the largest medieval states. The constant processes of interaction between cultures of different countries and religions that took place in it contributed to the prosperity of trade, science, and art. In addition, handicraft production was highly developed in Uchi Jochi. Urban craft included jewelry, pottery, construction, weaving, carving on various materials, various types of metalworking, etc. This diversity was due to the constant need for supply of many Golden Horde cities.

With the establishment of Islam as the state religion in the first quarter of the XIV century. There was a need for the mass construction of typical Muslim buildings. So, for example, the need to perform prayer five times (prayer) required constant ablutions, and religion itself presupposed keeping the body clean. This entailed the massive construction in the cities of Ulus Juchi of public baths of the eastern type "hammam".

Mosques, madrassas (higher educational institutions of theology) and other religious buildings that required rich decorative decoration began to be built in cities. It was with the advent of Islam in the Golden Horde that the production of architectural ceramics was put on stream.

\section{History of the Golden Horde hillforts:}

Surveys of the Golden Horde hillforts, begun in the 2nd floor. XVIII - beg. XIX centuries., Gave a large amount of material, which allowed to develop in detail a lot of both general and detailed questions of the history and culture of the Golden Horde and, in particular, urban culture. However, the question regarding the general typology of the decor of the architectural structures of the Golden Horde cities has been little developed, while the main source on this issue is archaeological data, updated annually.

\section{The aim of this study:}

The aim of this study was to review the general typology of the Golden Horde architectural decor, based on the analysis of disparate materials.

\section{Previously studies:}

The theme of the architectural decor of the Juchi cities was dealt with by such scientists as A.S. Voskresensky, L.M. Noskova and G.A. Fedorov-Davydov. 
Research A.S. Voskresensky reflected in publications in the journal

"Soviet archeology." So, for example, his article "Polychrome Majolica of the Golden Horde Volga Region" [3] is a generalization of the characteristics of household ceramics (utensils and architectural decor), painted in the style of polychrome majolica, given by A.Yu. Yakubovsky [15] and G.A. Fedorov-Davydov (excavations of 1962 in Saray-Berk). And the message is A.S. Voskresensky's "New Data on Irrigation Architectural Ceramics of the Golden Horde Volga Region" [2] contains information on the results of chemical analysis of fragments of architectural decor from 10 Golden Horde monuments.

Studies conducted by L.M. Noskova is much more thorough, and her work can be considered the only serious developments on the types of decor of architectural structures of the cities of the Golden Horde. It gives a complete classification of the samples found in Tsarevsky, Selitrenny, Uveksky, Vodyansky, Mechetny and Bulgarian hillforts from the very beginning of their survey and until 1974 inclusive, as well as during the PAE expedition to the Selitrennoye hillfort (excavations of the palace complex) in 1978-1980. [11] L.M. Noskova systematized the studied samples by material, purpose, by elements of murals and their combinations.

The classification of the architectural decoration of the Golden Horde given by G.A. Federov-Davydov [14], includes the typology of L. M. Noskova, supplemented by the author himself on the basis of his studies of the Golden Horde settlements.

Elements of architectural decor from the number of finds on the Golden Horde monuments include extensive, partially unexplored material. Consider the types of decor presented in the works of the previously mentioned researchers.

\section{Glazed kashinny and red clay architectural décor:}

As a rule, cachine and red clay served as raw materials for the manufacture of glazed architectural ceramics. The latter was the most common material in the construction business. Red clay products were produced in situ from loesslike clay rocks (loess is a crypto-layered, homogeneous calcareous sedimentary rock of light yellow or pale yellow color) and organic additives that burned out during firing, providing the product with a porous structure. Nevertheless, the main material for making the decor was kashin - a substance of silicate origin, consisting of sand, kaolin and feldspar, which served as glue. The appearance of kashin ceramics is associated with the use of transparent glazes, which required a light base. In Central Asia, kashin architectural ceramics has been known since the beginning of the XII century, and its appearance in the Golden Horde can be considered as a consequence of the influence of the Khorezm ceramic production [10, p. 23].

In any case, the bulk of the materials of the potters of a production center was local raw materials. Therefore, a thorough study of the rocks (for example, clays) in the area of an archaeological site and the composition of the architectural materials of this site makes sense to classify the items as one or another production point. This also allows you to consider possible options for transporting raw materials or the product itself, its processing, etc.

\section{Watering Bricks:}

Such products were made both from kashin, and on a red clay basis. One of the sides was covered with one-color glaze (white, yellow, turquoise, ultramarine). Their side planes were beveled and had grooves - so they were better fastened with a mortar, which sometimes also played a decorative role (when the seams between the bricks were specially made wide). These bricks laid out large ornamental panels, usually located at a distance from the viewer, which contributed to a complete perception of the composition.

Sometimes the surface of irrigation bricks was made convex for facing cylindrical architectural structures, for example, minarets or columns [14, p. 152].

By analogy with the Central Asian monuments, irrigation bricks were used to decorate dome surfaces, as well as for external cladding of buildings. According to archaeological excavations, it is also known that they laid out the floors in the premises. Often, irrigation bricks were used together with simple ones, forming ornamented surfaces. Inserts and bricks were fastened with alabaster [11, p. 172].

\section{Mosaic in kashin:}

Archaeological research has shown that mosaics covered rather large planes and made up large ornamental panels. However, it is almost impossible to restore the appearance of such panels because of the small size of the fragments [10, p. 7].

Mosaics, like irrigation bricks, were used to decorate surfaces remote from the viewer. As a result of this, each seemingly insignificant element fulfilled its function, at the same time merging with other fragments and forming an integral decorative composition. Mosaics were mainly used for facing portals, arches, side walls of pylons, inner dome arches, large planes of walls. 
The production of mosaics was a difficult, time-consuming business, and, therefore, quite expensive. In addition, the final appearance of the panel depended a lot on the technique of the master.

It is generally accepted that mosaics were made from pieces cut from monochrome majolica tiles. After cutting, the elements fit tightly to each other, and then assembled on smooth boards face down. The reverse side of the product was poured with a solution of gypsum for fastening all parts. The finished composition was installed on the desired surface [8, p. 37]. F.V. Ballod describes this method in more detail, indicating that after cutting the fragments were ground so that the underside was smaller than the irrigated surface. Then, after laying the ornament on the board face down, the pieces were wetted (for better adhesion to the gypsum mortar) and enclosed in frames [1, p. 115]. This method is called by modern mosaic masters the inverse set technique.

CM. Dudin in his article gives an example when individual particles of mosaics were cut out by applying a cloisonnecontour cutter-stencil to a wet layer of the bulk of the plate, after which watering was applied. The mass was fastened with alabaster [5, p. 183]. This method seems simpler and less costly than the first. Nevertheless, the result obtained was qualitatively lost to the usual mosaic (first of all, due to the smaller spectrum of shades).

There is also a direct dialing technique, historically the first among others, when sawn elements were installed immediately on the final surface, previously coated with a fastening solution. However, the Golden Horde mosaics were made only with the reverse set.

Immediately after the appearance of the mosaic in the Golden Horde cities, a search began for new equipment requiring less labor. Therefore, each mosaicist owned his own secrets of the set.

\section{Polychrome majolica in kashin:}

One of the alternatives to the mosaic was polychrome majolica - products from colored burnt clay with large-porous shards coated with glaze - simpler to execute, but not at all losing in the richness of ornaments and colors. They were designed, in contrast to mosaics, not to contemplate the composition from a distance, but rather they were used for parts of buildings located near the observer.

Majolica was a rectangular tiles covered with paintings. They were installed one to another, forming a single ornamental panel $[13, \mathrm{p}$.
213]. Painted majolica was used to design cornices, borders, side columns, to decorate mihrab niches and gravestones [8, $\mathrm{p}$. 37].

The Golden Horde architectural decor of this type is represented by kashin polychrome majolica with sub-glaze and overglaze painting. For underglaze painting, the use of transparent lead irrigation is typical, and for overglaze painting is deaf, tin. At the same time, underglaze painting was used much more often underglaze. The latter could be used only for tiles, which decorated the interiors of buildings. Because of their small size and small pattern, they were used only to decorate small surfaces.

According to the technique of drawing a pattern, majolica resembles glazed household ceramics. Comparison of these types of ceramic products $[3$, p. 79,84$]$ showed that the main types of household ceramic ceramics correspond to the main types of architectural cladding, although the ornaments differ significantly from each other. Of course, the influence of glazed ceramics on architectural decor is beyond doubt. However, it should be noted that there were types characteristic only of architectural facings.

Overglaze and underglaze polychrome majolica are characterized by floral, geometric and epigraphic types of ornaments.

The first option corresponds to floral arrangements, floral ornaments with a linear composition, endlessly repeating floral motifs and also murals highlighting the central figure (rosettes, stems, leaves) [10, p. 12-20]. L.P. Matveeva also highlights patterns made in a free manner, very close to nature [7, p. 221].

The second option is characterized by the presence of various geometric shapes, mainly triangular or hexagonal, or an ornament composed of rhombuses. Compositions of foureight-pointed stars with the inclusion of floral ornaments also fit in [14, p. 158].

In addition, in the underglaze paintings of L.M. Noskova distinguishes the so-called "braids" into a separate ornamental type [10, p. 16-17]. Although samples of this species should be attributed rather to geometric ornaments, as A.S. Voskresensky and L.P. Matveeva [3, p. 83; 7, p. 221]. In such samples, the geometric ornament is built according to the law of girih: endlessly intertwining lines, starting from one center, form a complex weaving, and at the centers of interlacing the pattern includes stylized floral rosettes that revive the composition.

The epigraphic ornament in majolica very rarely performed an independent role. More often it was used to frame the composition, and only in rare cases carried the main semantic load, combined with floral or geometric patterns. For this 
tapa, several options are characteristic: it is used as a framing belt, and the inscription is so stylized that it is sometimes difficult to decipher it; in another case - also a frame, but already an inscription in the full sense of the word, made by a round Naskh letter; and the third option, similar to the second, but the inscriptions are made in Kufic writing.

It should be noted that L.M. In the description of majolica with overglazed murals, the specimen depicting samples depicting a person. In the center of the composition is depicted a man with Mongoloid features: a round face, wide cheekbones, elongated eyes. He is dressed in traditional clothes, a hat. The composition is complemented by a free floral ornament. A similar fragment found on the Selitrennoe fortification is given in L.L. Galkina [4, p. 239-240].

In addition, a mixed type of majolica on caffeine stands out, combining underglaze and overglaze painting. It is characterized, in most cases, by a floral ornament, sometimes combined with geometric and epigraphic [10, p. 20-21].

Along with these samples, there is a form of the so-called "false mosaic", which can be attributed to majolica. These are plates with a polychrome ornament, the drawn contours of which create the appearance of a mosaic. They are characterized by geometric and epigraphic ornament [11, p. $182]$.

\section{Red clay majolica:}

Given the fact that a light base is desirable for polychrome painting of tiles, the red clay material for majolica is much less suitable. That is, it is cheaper and lower quality raw materials. The choice of such material was determined by the lack of expensive kashin. On Selitrennoy and Tsarevsky hillforts, kashin was used for decorative cladding, and as for other cities of the Golden Horde, here we meet with architectural decor, made not from pure white kashin anymore, but with a large admixture of ordinary clay (this gave the kashin a pinkish tint). Although similar examples are known in the already mentioned fortifications. The red clay admixtures in the kashin test indicate the local origin of the products.

There is red-clay majolica with turquoise transparent watering and polychrome, mostly white, pattern under watering.

Along with them there are red-clay false mosaics, the pattern of which had a deep cut black line separating the color fields covered with opaque glaze [13, p. 215]. False mosaics covered both the even parts of the building and mukarnas decorative details in the form of prismatic figures located protruding one above the other (reminiscent of stalactites in caves). In general, the kashin base was used more often, because more suited for painting.
The determining role as a tile was played by watering (or glaze) - a vitreous mass, the determining component of which was lead oxide. But the Golden Horde was characterized by the use of lead-free glazes, more resistant to atmospheric phenomena. The palette used in mosaics and majolica included two achromatic colors (black and white), as well as 6 chromatic ones: yellow, green, blue, blue, red and brown.

Majolica plates were fired in ceramic furnaces (hearths).

Majolica was burned in three ways [10, p. 24-25].

One-color fragments, previously englobed or without englobe, were glazed and fired in pottery kilns (the so-called technology of single firing).

The manufacturing process of polychrome majolica was much more complicated, since each paint required a certain temperature regime during firing, which greatly affected the color purity of the finished product. Initially, the cereal dough was poured into a pre-prepared form, the product was dried, and after that, the technology of double firing was applied. There are 2 options:

1) First, the non-abused base was fired, then englobe and paints were applied and secondary firing was performed.

2) Another option: first the product is burned, covered with engobe and paints, and then it is covered with glaze and burned again.

There was a triple firing, used for embossed majolica. In order to make such tiles, the raw caffeine mass was poured into molds (wooden or alabaster), dried, and then an ornament was stamped and burned using a stamp (also wooden or alabaster). Already once burnt tiles were covered with deaf glaze and burned again. The third firing was carried out after applying the overglaze pattern. The final firing temperature ranged from $850-1000^{\circ} \mathrm{C}$.

\section{Terracotta décor:}

This type of architectural decor is represented by carved and stamped terracotta tiles made of red-yellow dense clay with and without watering. Such products were usually covered with opaque white, blue, green, ultramarine watering, or with a combination of watering these colors [13, p. 217]. This type of decor was used to decorate corners, friezes, borders.

Terracotta (terracotta - yellow-red burnt pottery clay) carved plates appear in Central Asia as early as the XII century, first in Samarkand and Bukhara, and then in Khorezm. Its use in architectural decor was due not only to the convenience of artistic processing, but also to the durability of the material. Carved terracotta created the possibility of an extraordinary flowering of decorative art. Cladding with terracotta tiles 
attached to masonry has opened a new page in architecture. Before its appearance, decorative textures were associated with masonry, depended on it and revealed its essence. Terracotta plates made it possible to create a cladding completely independent of the base that supports it $[6, \mathrm{p} .50]$.

The use of terracotta decor was especially pronounced in the Central Asian art of the XIV century, just at that time, during which the cultural and economic heyday of the Golden Horde cities fell.

For the carved and stamped terra cotta of the Golden Horde, vegetative, geometric and epigraphic types of ornaments are characteristic; there are combinations. It is characteristic that, with any type, the elements of the ornament combine to form a complex weave, and only occasionally separate central figures. Occasionally, apparently, finished products come in the form of carved terracotta tiles without watering. There are carved terracotta tiles with a partial coating of turquoise glaze of the main elements of the ornament. Stamped tiles had a smaller relief and were used to decorate the planes of walls, corners, cornices, tombstones, etc. [14, p. 152, 159-161].

It should be noted that carved and stamped terracotta began to be used more readily with the advent of watering in the XI-XII centuries: glazed tiles that did not absorb moisture were a more practical material.

The Golden Horde terracotta décor was peculiar, enriched borrowed Central Asian motifs with newly invented ornaments, and technique of execution [14, p. 166].

\section{Ganch décor:}

This type of decor is represented by carved and stamped tiles of a grayish color from the special composition of alabaster. Most often, such tiles had carved and openwork ornament, they formed the internal walls of buildings (external - less often), as well as mukarn. Panjars (gratings) for windows were also made from carved ganch - a cementitious material obtained by firing rock-like rocks containing gypsum and clay. They often had round holes with patterned edges to which glass window discs, sometimes colored, were glued from the inside. Some window grilles have a protruding edge painted red. Sometimes the background of carved and stamped ganch tiles was painted in such a color [14, p. 152].

Carved ganch was decorated with openwork ornament in the form of circles and curved shapes. Often used the motif of regular geometric lattices, widespread in the medieval Muslim world.

The ornaments decorating the ganch were similar to the ornaments of carved and stamped terracotta. In addition, there are simple motifs: grids of rhombic cells.
As for the technology of processing ganch, alabaster boards were preserved, which served as matrices for imprinting the pattern on a raw ganch surface. On the matrices, the pattern is in-depth. Stone matrix slabs are also known, by the way, found by A.V. Tereshchenko on Tsarevsky settlement.

Openwork and figured plates were superimposed in some cases on smooth surfaces, which added relief and expressiveness of the play of light and shadow to this kind of decor [14, p. 161-162].

Of course, the Golden Horde ganch is a borrowing from Central Asian ornamental art. But one should not forget about the elements of independence, manifested, for example, in some ganch elements that adorned stalactitesmukarny [14, p. 166].

Stone slabs with carved ornaments and stucco painting on the Golden Horde hillforts are much less common than other decorative architectural elements. In addition, carved stone slabs and plaster cannot be attributed to architectural ceramics, which include all the above types of decor.

Sometimes there are slabs made of marble, but still more often - from other types of stone, more affordable and cheaper [13, p. 217].

Dry plaster painting was used to decorate rich buildings. This technique is called al-piece. The palette is still unchanged: black, red, brown, green, yellow and blue colors are used. Sometimes the already rich painting was decorated with gilding or relief on the plaster [14, p. 153]. In the art of the Middle East (in particular, Syria and Iraq) of the 13th century, the technique of polishing stucco is also known, when using which the surface became like a marble one. But when studying the Golden Horde monuments, a similar processing method is not found. Nevertheless, examples are known when the drawing was not applied to the plaster, but cut through it. It could be a field for playing "Babylon", or simply images of animals, birds, people, inscriptions, etc. [12, p. 97].

As for the question of the origin of the traditions of the Golden Horde architectural decoration, it is definitely not limited to one direction. A characteristic feature of Ulus Jochi was extensive trade and cultural ties with many peoples: the closest were, initially, relations with China, Iran and Central Asia. Of course, Iran and Central Asia were also much influenced by China, thanks to which we can observe common motives and techniques in the architectural decoration of these countries [1, p. 117-118]. In addition, in the XIII century, the Central Asian region and Transcaucasia were at the center of one cycle of events: the Mongol conquest disrupted the natural course of not only their economic development, but also cultural. Khorezm, partially Transcaucasia and the Volga region, having fallen under the power of the Golden Horde khans, turned out to be bound by 
common borders, which could not but affect their cultural appearance $[10$, p. 28]. When Islam penetrated the Volga region at the beginning of the 14th century, Central Asia, Iran and Transcaucasia became the first sources of Muslim art traditions for the Golden Horde. And here it is important to note that the dominant ornamental style in Muslim art extended to all kinds of architectural decor, whether it be mosaics or majolica, terracotta or ganch, stone or plaster.

As for the question of the origin of the traditions of the Golden Horde architectural decoration, it is definitely not limited to one direction. A characteristic feature of Ulus Jochi was extensive trade and cultural ties with many peoples: the closest were, initially, relations with China, Iran and Central Asia. Of course, Iran and Central Asia were also much influenced by China, thanks to which we can observe common motives and techniques in the architectural decoration of these countries [1, p. 117-118]. In addition, in the XIII century, the Central Asian region and Transcaucasia were at the center of one cycle of events: The Mongol conquest disrupted the natural course of not only their economic development, but also cultural. Khorezm, partially Transcaucasia and the Volga region, having fallen under the power of the Golden Horde khans, turned out to be bound by common borders, which could not but affect their cultural appearance [10, p. 28]. When Islam penetrated the Volga region at the beginning of the 14th century, Central Asia, Iran and Transcaucasia became the first sources of Muslim art traditions for the Golden Horde. And here it is important to note that the dominant ornamental style in Muslim art extended to all kinds of architectural decor, whether it be mosaics or majolica, terracotta or ganch, stone or plaster.

Typical for Jochid architecture is the use of gilding to decorate the decor. This technique is known in the 11 th century Armenian architecture, where gypsum cladding was covered with gilding. On the Golden Horde majolica there is gilding according to the central figure - most often on a socket with 6 or 8 petals.

\section{Results and Conclusion:}

From here you can distinguish the following types of decoration:

It seems possible to distinguish the following general types of decor, presented as in the studies of A.Yu. Yakubovsky [15] and A.S. Voskresensky [3], and in more thorough works of G.A. Fedorov-Davydov [12, 13, 14] and L. M. Noskovaya [9, 10, 11]:

1) Irrigation kashin and red clay architectural decor:

- $\quad$ rectangular bricks covered with watering on one side;

- convex facing irrigation bricks;
- mosaic;

- polychrome majolica;

- $\quad$ polychrome majolica with gilding.

2) Terracotta decor:

- $\quad$ carved terracotta tiles;

- stamped terracotta tiles.

- 3) Ganch decor:

- carved ganch;

- stamped ganch.

4) Stone carved decor.

5) Painted plaster in the technique of "al-piece."

\section{References}

[1] Ballod F.V. Volga Pompeii. M.: State Publishing House, 1923.

[2] Resurrection A.S. New data on glazed architectural ceramics of the Golden Horde Volga // Soviet archeology. 1970. No. 1. S. 263-265.

[3] Resurrection A.S. Polychrome majolica of the Golden Horde Volga //Soviet archeology. 1967. No. 2. S. 79-90.

[4] Galkin L.L. Several tiles from Selitrennaya fortification // Soviet archeology. 1968. No. 3. S.238-244.

[5] Dudin S.M. To the question of the technique of tiled mosaics of Central Asia // Bulletin of the Russian Academy of the History of Material Culture. L., 1925.

[6] Zasypkin B.N. Essays on the history of architecture of the peoples of the USSR. Architecture of Central Asia. M.: Publishing House of the Academy of Architecture of the USSR, 1948.

[7] Matveeva L.P. Glazed tiles from the Bulgarians // Soviet archeology. 1959. No. 2. S.218-227.

[8] Nadiroa H.G. The architecture of the cities of the Golden Horde // News of KazGASU. 2008. No1 (9). S.33-38.

[9] Noskota L.M. The decoration of the palace complex in Sarai (Selitrennoe settlement) // Soviet archeology. 1984. No. 4. S.224-237.

[10] Noskova L.M. Mosaics and majolica from the medieval cities of the Volga region //Medieval Volga monuments in the Middle Ages. M.: Nauka, 1976. S. 7-37.

[11] Noskova L.M. Irrigation architectural decor from SarayBatu (Selitrennoe settlement) // Soviet archeology. 1972. No. 1. S.171-184. 
International Journal of Engineering Research and Technology. ISSN 0974-3154, Volume 13, Number 1 (2020), pp. 73-79

(C) International Research Publication House. https://dx.doi.org/10.37624/IJERT/13.1.2020.73-79

[12] Fedorov-Davydov G.A. Some results of the study of the cities of the Golden Horde on the Lower Volga // Tatar archeology. 1997. No1. S.92-104.

[13] Fedorov-Davydov G.A., Bulatov N.M. Ceramics workshop of Selitrennoye settlement // Treasures of Sarmatian leaders and the ancient cities of the Volga region. M., 1989. S.133-281.

[14] Fedorov-Davydov, G. A. The Golden Horde cities of the Volga region. M.: Moscow Publishing House. unta, 1994.232s.

[15] Yakubovsky A.Yu. To the question of the origin of the handicraft industry of Sarai Berke // Izvestia Gos. Academy of the History of Material Culture. 1931. T. 8. Issue. 2-3. S.1-48. 